\title{
BOOk Reviewg
}

The Effects of Tropical Light on White Mem By MAJor Charles E. Woodrufr, A. M., M. D., Surgeon U. S. Army, New York, Rebman Company, I905.

The idée-mère of this book, according to Dr. Woodruff himself, was announced by von Schmaedel before the Anthropological Society of Munich in 1895 . It is that the dermal pigmentation of man was evolved for the purpose of excluding the dangerous actinic or short light-rays, which destroy living protoplasm. With our newly acquired tropical possessions, and the extension of American "spheres of influence" into warmer climates, the subject must be most pertinent and suggestive. Indeed all Anglosaxondom and teutonism seems to have started in to carry Caucasian civilization into equatorial countries, so that Major Woodruff's timely and learned work will command the attention of all governmental, administrative, and medical classes.

The book is divided into 13 chapters, and the titles of these may, in a way, serve to indicate the data for, and trend of the theories advanced:

I. Zoological Zones.

II. Ether waves.

III. Action of Ether waves on Protoplasm.

IV. Difference between Plants and Animals.

V. Natural Defences of Animals from Light.

VI. Known Effects of Light on Man.

VII. Actinotherapy.

VIII. Blondness of Aryans.

IX. Evolution of Blondness.

X. Results of Insufficient Pigmentation.

XI. Results of Migration of Blond Races.

XII. Results of Migrations to America.

XIII. Practical Rules for White Men in the Tropics.

In his first chapter Dr. Woodruff points out the general law of adjustments to more or less definitely marked isothermal and zoologic zones which, within these lines, produces similar characteristics, colorations, etc., in animals and man. For instance, Simia, it is said, means the snubnosed one, and all Simians are tropical in origin, and human babies have snub-noses, the adult nose being narrower and longer in colder climes, and shorter and more open in the tropics. This is one reason for the pulmonary troubles of the negro transplanted to the north. The amount of pigmentation of the skin follows a similar law, although the theory 
should account for the comparative uniformity of the aborigines in this respect, whether living in Alaska or in Mexico and Peru. But the pigment of the cells below the outer layer do undoubtedly exercise a discriminating office in excluding or neutralizing the rays of the upper end of the spectrum. It is, however, questionable if the greater morbidity to which albinism is subject is not generally due to the lack of iris and retinal pigment, seemingly a small part of the general pigment-endowment, which unfits the animal or man for vision which is the sine qua non of activity and usefulness. But whatever the theory adopted as to the method of producing injury there can be little doubt that the shorter ether waves have in the long run a more destructive effect on living tissues than those of the longer or heat rays. Proof of this is abundantly supplied. The injurious effect of light upon bacteria is in direct corroboration, and that the majority of animals live in comparative darkness points to the same law. Even white feathers and fur are relatively opaque, and black pigmentation has the function of a reducer transforming as it were a high-tension to a low-tension current. Moreover, men have usually lived in dark houses, though again it must not be forgotten that the action of light upon the retina destroys its sensitiveness, diminishing the usefulness of the man, and even producing "moon blindness," etc. The old name for migraine was "sun-pain," and sufferers shrink from light, but migraine is due to errors of refraction, and light is avoided because it induces function and greater eye strain, not because even tropical light is unpleasant or harmful to an emmetropic eye. It would be interesting to know what proportion of hay-fever patients are blonds. In Chapter VII there is a capital epitome of medical literature on the effects of tropical light on white men.

Primitive man was brunet, not black, and so were the early Britons, but the Aryans were blonds, and they are conquering the brunets everywhere.

Practical results are reached in the conclusion that final exhaustion follows the first few months of stimulation of the Caucasian transplanted to the tropics. If this apepsia and debility increases Dr. Woodruff commends the moderate use of alcohol in these conditions. Neurasthenia, amnesia, sun pain, other neuroses, and even insanity often result from continued residence, all ultimately traced to the lack of protection from too much light. The general conclusion is reached that suicide depends somewhat upon the amount of light, the time of the year, etc. That the insanity rate in the Philippines is not greater is due to the fact that upon the approach of extreme neurasthenic and threatening symptoms the patients are sent home to the United States. All of this, of course does not prove that in our cloudy and northern climes there may be too little sunlight and that disease does not follow close upon this too little.

As regards the relative amount of sunshine the rule is deduced that, "the death-rate of a place is proportional to its sunshine, and inversely proportional to its latitude-other factors being eliminated," and the 
people of Tacoma, Seattle and this region attribute their exuberant health, small death-rate, and morbidity, to every cause except the correct oneprotection from sunshine. The order therefore is, Delay the destruction of the dwindling blonds. In the tropics opaque clothing is demanded, the color being comparatively immaterial, so it reflects as much heat as possible. Opaque head coverings, and darkened rooms, the midday siesta, etc., are also necessary. The best age of those going to the tropics is from 20 to 30 , or 35 , and none over 50 should think of life there. Prompt invaliding or pensioning are advisable upon ingravescence of neurasthenic symptoms. Dr. Woodruff laments the great ignorance and lack of interest in the subject of tropical hygiene, and the fact that the valuable experience of hundreds of physicians returning to the United States, is lost, and not placed at the service of the new men taking their places. The last words of the book require literal quotation:

"It is hoped that this investigation will take us a step nearer to the solution of that problem which is now confronting the American people as well as European nations-The Conquest of the Tropics, to give to its peoples that security of life and property, and that civilization and prosperity, which they cannot attain by their own unaided efforts, in an unsuitable form of government forced upon them by the Monroe Doctrine for our own welfare."

G. M. G.

Diseases of the Nervous System. By L. Harrison Mettler, A. M., M. D., etc., (Chicago: Cleveland Press, 1905.)

The value which this work undoubtedly possesses as a treatise on clinical neurology is somewhat counterbalanced by the author's neuronic dogmatism. One takes alarm first in the preface, where the opening sentence concisely asserts that "The Neuron Doctrine is now an accepted fact;" and when further it appears that in nearly a thousand pages following, the subject of nervous diseases is considered entirely " under the brilliant illumination" of this "accepted fact," which, moreover, is "universally acknowledged to be scientifically accurate" (!), one instinctively turns the pages for evidence. In lieu of evidence, however, one has to be content with the ipse dixit of the author, who "feels that the time has arrived for the frank recognition of this great doctrine, not merely in histology, but also in the greater field of neurology." It is, therefore, an unexpected consolation to find the author conceding, a few pages later, that the neurone theory "is not put forth as an infallible truth. It is open to future modification, and if need be to entire annihilation. . ..." So there is still room for those who have hitherto been unable to regard the hypothesis of Waldeyer as an established fact. To set authority against authority, we mention the remarkable critique of $\mathrm{Nissl}^{1}{ }^{1}$ who in 470 pages of unequivocal language attacks the theory which in its widespread influence he considers "ein Unglück und eine Gefahr für den Fortschritt in unserer wissen-

1 "Die Neuronenlehre und ihre Anhänger," 1903. 